\title{
Mobil Teknolojinin Perakendecilik Üzerindeki Etkileri
}

\begin{abstract}
İzzet Gülşen ${ }^{1}$
Şuayıp Özdemir²

Mobil Teknolojinin Perakendecilik Üzerindeki Etkileri

Öz

$\mathrm{Bu}$ çalışmanın amacı, perakendeciliği etkileyen önemli faktörleri analiz ederek perakendeciliğin geleceği ile ilgili öngörülerde bulunmaktır. Tek başına mobil teknolojinin perakendecilikteki değişimi açıklamakta yetersiz kalacağı düşüncesiyle, teknolojiyle bağlantılı olarak tüketiciler, organizasyon, rekabet, lojistik ve pazarlama iletişimindeki değişim üzerinde durulmuştur. Elbette çalışmada ağırlıklı olarak mobil teknolojinin etkileri ele alınmıştır. Mobil teknolojinin doğrudan ya da dolaylı olarak perakendeciliğ $i$ nasıl etkilediği, buna bağlı olarak perakendecilerde nasıl bir yapısal dönüşüme neden olduğu konusu, literatüre dayalı olarak ve sektördeki gelişmelere bağıı olarak örnek olaylar üzerinden analiz edilmiştir. Mobil teknolojinin, müşteri ile iletişim biçimi ve içeriğini, perakendeciliğin organizasyonunu, sektörde yaşanacak rekabetin yönünü etkilediği tespit edilmiştir. Tüm bu alanlardaki değişimin bütün olarak ele alındığında perakendecilik için önemli sayılabilecek değişikliklerin işaretleri olabileceği öngörül-

\author{
The Effects of Mobile Technology on Retailing \\ Abstract
}

The aim of this study is to make predictions about the future of retailing by analyzing the important factors affecting retailing. In view of the fact that mobile technology alone would be insufficient to explain the change in retailing, the changes in consumers, organization, competition, logistics and marketing communication in relation to technology are emphasized. Of course, the study mainly deals with the effects of mobile technology. How mobile technology directly or indirectly affects retailing and, accordingly, how it causes structural transformation in retailers has been analyzed on the basis of literature and case studies based on developments in the sector. It has been determined that mobile technology affects the form and content of communication with the customer, the organization of retailing and the direction of competition in the sector. Considering the change in all these areas as a whole, it is predicted that there may be signs of changes that can be considered important for retailing.
\end{abstract} müştür.

Anahtar Kelimeler: Dijital Dönüşüm, Mobil Teknoloji, Mobil Pazarlama, Mobil illetişim, Perakendecilik
Keywords: Digital Transformation, Mobile Technology, Mobile Marketing, Mobile Communication, Retailing

\section{Giriş}

Bu çalışmanın amacı dijital dünyanın ve mobil teknolojinin perakendeciliği nasıl dönüştürdüğünü literatüre dayalı olarak ve örnek olaylar yardımıyla açıklamaya çalışmak ve bu yolla gelecek hakkında öngörülerde bulunmaktır. Perakendecilikle ilişkili olarak kullanılan teknolojilerin perakendeciliği nasıl dönüştüreceğine ilişkin araştırmaların sayısı giderek artmaktadır. Eldeki verilerle tutarlı biçimde öngörüde bulunmak artık bir gereklilik halini almıştır. Bu bağlamda çaıışmada, hem pazarlama uygulayıcıları hem de akademik alanda sık irdelenen mobil teknolojinin "perakendecilik sektörü üzerinde nasıl bir değişim ve dönüşüm getirdiği" sorusunun cevabı aranmaktadır. Soruya cevap ararken daha önce yapılmış akademik çalışmalardan ve sektörde yer alan ve fiili uygulamalardan hareket edilmektedir.

Günümüzde perakendecilik sektöründe bir taraftan yoğun bir rekabet yaşanırken, diğer taraftan pazarın istek ve ihtiyaçaları doğrultusunda daha hızlı ve yenilikçi bir üretim çağına girildiği söylenebilir. Bu bağlamda, perakende satış noktalarında ya eşdeğer özellikte ya da birbirine benzer özelliklere sahip ürünlerin içerisinde bir ürünün diğerinden ayrıştıracak; diğer bir ifade ile bir mağazayı diğer bir mağazadan ayrıştıracak "benzersiz değer" önermesi ihtimali her geçen

\footnotetext{
${ }^{1}$ Dr., izzet.gulsen@gmail.com, yazar ORCID bilgisi: https://orcid.org/0000-0001-5369-1130.

2 Prof. Dr., Afyon Kocatepe Üniversitesi, iiBF, İşletme Bölümü. suayb@hotmail.com, yazar ORCID bilgisi: https://orcid.org/0000-0002-6799-8480.
} 
gün zayıflamaktadır. Bu gelişmeler, perakendecileri geleneksel pazarlama yöntemlerinin dışında, tüketicilerle iletişimin holistik pazarlama anlayışıyla özellikle "satış noktalarında ve dağıtım kanallarında" tüketicilerin istek ve ihtiyaçlarına daha yüksek değerler katacak etkili ve yenilikçi pazarlama uygulamaya zorunlu kılmaktadır.

İnsanlık tarihi boyunca küçük değişimlerle bugüne kadar gelmiş olan perakendecilik yaşanan teknolojik ve sosyal değişimlerle ani ve büyük bir değişimin eşiğinde durmaktadır.

Elde taşınabilir mobil cihazlar her geçen gün daha belirgin ve yaygın bir şekilde aktif olarak kullanılmaktadır. Bu eğilimlere bağlı olarak mobil cihazlar, etkili bir pazarlama iletişimi aracı ve mecrası olarak hem akademik literatürde hem de bütün sektörlerdeki pazarlama uygulayıcılarının dikkatlerini üzerine çekmiştir. Shankar vd. (2010: 111)'nin ifadesine göre mobil pazarlama, perakendecilik endüstrisinde giderek daha çok önem kazanmaktadır. Mobil ortam ve cihazların oluşturduğu fırsatlarla birlikte tüketicilerin alışveriş yaptığı yerleri seçmeye ve alışveriş için belirli bir zaman dilimini ayırmaya ait duyarlılı̆ı azalmaktadır. Pazarlama karmasının bir elemanı olan dağıtım ile ilgili olarak duyarlılığı düşürme ve bu bileşenin kabuk değiştirmesine yol açacak bir değişim gibi durmaktadır. Artık tüketiciler perakendeci mağazalardaki raflardan ürün seçerek taşımak yerine mobil uygulamalardan daha çok ürün karşılaştırması, tedarikçi seçimi ve kullanıc yorumlarını da inceleyerek daha çok alternatifi daha kısa sürede ve daha ucuza değerlendirme şansını yakalamaktadır. Bu durum, mobil pazarlamanın, perakendecilik anlayışını ve uygulamalarını değiştirme potansiyeline sahip olduğunu göstermektedir. Perakendeciler artık tüketicinin bulundukları ortamlara mobil cihazlar aracılı̆̆ıyla girebilmektedir. Çünkü mobil cihazlar tüketici ile birlikte dolaşmakta ve dolayısıyla perakendeciler her zaman ve her yerde hedef müşterilerle olabilme fırsatını oluşturabilmektedirler. Üstelik mobil cihazlardaki sensörler ve kullanıcı isimleri yoluyla tüketicileri birebir takip ederek onlara özel öneriler getirme şansına da sahip olabilmektedirler.

Perakendecilik, tüketici davranışlarındaki değişimler doğrultusunda geçmişten gümüze kadar geçen zaman içerisinde sürekli bir değişim yaşamıştır. Ekonomik ve sosyal koşullar, demografik değişimler, teknolojiye dayalı sanayileşme, iletişim alanlarındaki gelişmeler, perakendeciliğin değişiminde temel rol oynayan unsurlar olarak kabul edilmektedir (Samson, 1969: 15). Toplumsal yapı, kentlerin tasarımı, iletişim ve ulaşım teknolojilerindeki değişimlerin yanında tüketici talepleri ve davranışları değiştikçe yeni perakendecilik sektörünün yaşadığı değişim de sürmektedir. Mobil teknoloji insanlararası iletişim biçimlerini ve sıklıklarını etkilediği gibi bireysel insan davranışını ve düşünme biçimini de etkilemektedir. Tüm bunlar birlikte düşünüldüğünde geleceğin perakendeciliğinin, mobil teknoloji ve internetle yakından ilgili olduğunu tahmin etmek mümkündür.

\section{Perakendecilik Sektöründe Değişim Dinamiği Olarak Teknoloji}

Teknoloji, "en basit haliyle yeni bir iş modelinin oluşumuna olanak sağlayan altyapıdır".Teknolojik gelişmeleri anlamak, pazarlamacılar için çeşitli nedenlerden dolayı önemlidir. En başta teknoloji bir makro çevre değişkeni olarak işletmeyi tüm dünyadaki işletmeleri er ya da geç etkilemektedir. Varlığını sürdürmek isteyen işletmelerin teknolojiyi takip etmeleri ve kullanmaları gerekmektedir. Teknolojik değişim, ekonomik büyümenin itici güçlerinden birisidir. Yeni markaların büyümesini ve yeni pazarların oluşumunu sağlamaktadır (Gülşen ve Özdemir, 2018:105). İnsansız yer ve hava araçları (drone), hyperloop teknolojisi, sayıları ve çeşitleri artarak yaygın kullanılan ısı, ses, hız, basınç ve yön sensörleri teknolojiyi insan hayatına sokmuştur. Dijital dünya, bilgisayar ve iletişim teknolojisi, ödeme ve ulaştırma teknolojisi, otomasyon, barkod, karekod ve nesnelerin interneti, küresel konum takip sistemi, beacon teknolojisi, yapay zeka ve 
akıllı sistemler, ürünü ve tüketiciyi takip ederek duruma göre teklifler sunan sistemler teknoloji başlığı altında değerlendirilmektedir. Ayrıca bilişim teknolojisi olarak isimlendirilen ve bilgisayarlara bağlı olarak çalışan ve farklı işlevleri yerine getirebilen çok sayıda elektronik cihaz yeni bir bütün oluşturmaktadır. Kablosuz ve mobil iletişim, mobil bilgi işlem teknolojisi, bulut bilişim sistemleri, yaygın internet, sesli ve görsel dijital iletişim, sürekli veri toplayan dinamik veri tabanları, karar destek sistemleri de teknoloji başlığı altında değerlendirilmektedir.

Bir makro çevre değişkeni olarak teknolojide yaşanan değişim hemen her alanda değişimlere yol açmaktadır. Teknoloji kullanarak otomasyonu sağlamaya, maliyetleri düşürmeye, müşteri memnuniyetini sağlamaya çalışan perakendecilik sektörü teknolojiden etkilenen sektörlerin başında gelmektedir. Teknoloji dolaylı olarak perakendecilik sektörüne hizmet veren sektörler üzerinden perakendeciliği etkileyebildiği gibi doğrudan perakendecilikte kullanılan veya kullanılma potansiyeli taşıyan teknolojilerle sektörü etkilemektedir.

\section{Mobil iletişim}

Cep telefonları ve akıllı telefonlar, kablosuz internet bağlantıları "mobil tüketicileri" her zaman ve hemen her yerde ulaşılabilir hale getirmektedir. Mobil pazarlama, mobil cihazlar aracıIığıyla hareket halindeki tüketicilere sunulan "pazarlama mesajları, tutundurma ve diğer pazarlama içeriklerini” oluşturur. Pazarlamacılar pek çok alanda satın alma ve ilişkileri geliştirme süreçlerinde müşterilere ulaşabilmek için mobil pazarlama yöntemlerini kullanmaktadırlar. Bu durum, mobil cihazların yaygın olarak benimsenmesi ve mobil web trafiğindeki artış, gelecekte ayakta kalmak isteyen işletmelerin mobil pazarlama yöntemlerini aktif kullanmaları gerektiğini göstermektedir (Kotler ve Armstrong, 2018: 525).

Basit bir şekilde ifade etmek gerekirse mobil pazarlama, internet erişimli taşınabilir bilgisayarlar ve mobil telefonlar aracılığıyla gerçekleştirilen pazarlama faaliyetleridir. Mobil telefonların büyüyen ekranları, artan işlem ve depolama kapasiteleri, yüksek hızlı internet erişimine sahip olmaları tabletlerin aynı zamanda "taşınabilir bilgisayar kapasitesine sahip" olma özelliği kazandırmıştır. Bundan dolayı mobil pazarlama denildiğinde (cep telefonunun İngilizce karşıı̆ı̆ olan "mobile" kelimesinden de destek alarak) akıllı telefonlarla yapılan pazarlama iletişimleri anlaşılmaktadır. Bu yönüyle mobil telefonlar, mobil pazarlamanın temel araçlarındandır.

Gelişen teknolojik yenilikler ile beraber mobil iletişim cihazları önce temel özellikli telefonlardan akıllı telefonlara (smartphones), sonra da tablet bilgisayarların özelliklerini de içerecek şekilde dönüşerek "phablets"e dönüşmüş durumdadır. 2020 yılı itibarıyla giyilebilir teknolojilerin, örneğin akıllı saatler pazarının küresel olarak 32,9 milyar ABD dolarına ulaşması beklenirken pazarlama iletişiminde de değişikliklere yol açması beklenmektedir. Öte yandan, gelişen teknolojilerden kişiselleştirilmiş pazarlama iletişiminin (örneğin 'beacons' teknolojisi) etkisi kanıtlandıkça pazarlama harcamalarını mobil cihazlara doğru daha da ileri bir seviyeye götürmesi beklenebilir. Birçok işletme, mobil pazarlama ve mobil teknoloji trendlerinden etkilenmektedir. Değişim, iş yapma biçimini değiştirebildiği gibi, daha büyük işletmelerle işbirliği yapılması ya da bazı işletmelerin pazardan çekilmesiyle de sonuçlanabilmektedir. Mobil iletişim teknolojilerinin gelişmesinden ve yaygınlaşmasından en çok etkilenen sektörlerden birisinin de perakendecilik sektörü olduğu söylenebilir.

2017 yılı ortalarında açıklanan rapora göre dünya nüfusunun \%67'si akıllı telefon kullanmaktadır (Karadağ, 2017). 2018 yılı başında yayınlanan bir rapora göre dünyada mobil internet kullanım oranı \%56 olmuştur (Kemp, 2018). Artık internet kullanımının yarısından fazlası akıllı telefonlardan sağlanmaktadır. Aynı rapora göre akıllı telefon kullanıcıları günde 6 saat internette 
zaman harcamaktadırlar. Bir kişinin 6 saat uyuduğu ve cihaz kullanmadığı varsayılırsa gününün 3'te 1'ini internete bağlı olarak geçirmektedir. Internette harcanan zamanının çoğunun sosyal medyada geçirildiği de aynı raporda ifade edilmektedir. Ancak bu rakamlar göstermektedir ki tüketiciye ulaşmanın yolu artık akıllı telefonlardan geçmektedir.

Bu veriler, aynı zamanda mobil perakendeciliğin artarak büyümesinin kaçınılmaz olduğu göstermektedir. Mobili iletişim araçları olarak kabul edilebilecek "Google Glass, Apple Watch" gibi giyilebilir mobil teknolojiler, "müşterilere ulaşmak için yeni fırsatlar" oluşturmaktadır. Dolayısıyla, perakendeci işletmelerin, perakendecilik sektörünü yakından takip etmenin yanında, mobil iletişim alanındaki yenilikleri de yakından takip etmelerini gerekli kılmaktadır. Mobil pazarlama bağlamında, perakendecilerin mağaza içinde "ücretsiz Wi-Fi sunarak ve web sitelerini mobil dostu olarak düzenleyerek tüketicilerine ulaşmaya çalışan perakendeciler" bulunmaktadır (Deloitte, 2015: 4).

Perakendecilik sektöründe bu gelişme trendlerinden yararlanmak isteyen pek çok perakendeci kuruluşun bir mobil uygulaması bulunmaktadır. Bu uygulamaların özellikleri, perakendeciler arasında farklılıklar göstermektedir. Bazıları "mağaza bulma, kuponları indirme veya haftalık aktüel ürünler kataloğunu elektronik olarak görüntüleme" gibi nispeten sınırlı seçenekler sunarken, diğerleri "bütünleşik kanal deneyimi” (omnichannel) sunmaktadır. Örneğin, ABD'de faaliyet gösteren perakendeci Target'ın mobil uygulaması, "müşterilerine taradıkları ürünlerle ilgili özel bir kampanyanın olup olmadığını, mağaza içerisinde hareket ettikleri sırada mobil kupon elde etmeyi, mağaza içindeki ürünleri bulmak için bulundukları mağaza haritasını indirmeyi ve online alışveriş yapmalarını" sağlamaktadır (Gülşen ve Özdemir, 2018:116; Inman ve Nikolova, 2017: 10).

Mobil pazarlama faaliyetleri, mobil telefonlar aracılığıyla gerçekleştirilmesinden dolayı mobil telefon ve mobil pazarlama arasında önemli bir ilişki vardır. Mobil telefonların, pazarlama faaliyetleri için önemli olmasının nedenleri; (1) müşterilerin mobil telefonlarını her zaman, her yerde yanında taşıması, (2) her zaman iletişime açık olması, (3) müşterilerle bire bir iletişim kurulmasının daha fazla ilgi çekmesi, (4) müşterilerin gönderilen mesajları kaydederek daha sonra yanıtlayabilmeleri, (5) müşteriler ile bire bir sesli ve görüntülü iletişim kurma imkânı vermesi, (6) müşteriler için uygunluk ve (7) pazarlama yöneticileri için etkinlik sağlaması olarak da sıralanabilir. Buna göre mobil telefonlar, geniş kitlelere etkin şekilde ulaşabilen hedef kitlelere her yerde ve her zamanda etkileşim kurabilen doğrudan pazarlama aracıdır (Yuan ve Cheng, 2004; akt: Barutçu ve Göl, 2009: 25; Barutçu, 2008: 263- 281 ). Ayrıca mobil telefonlar (8) anlık iletişim kurma imkânı sunarak işletmenin tutundurma mesajlarını hedef kişilere iletme imkânı sunmakta, (9) tüketicilerin, omnichannel adı verilen yöntemle aynı anda çok sayıda kanalı kullanmasına imkân sunmakta, (10) bir ödeme cihazı olarak kullanılabilmekte, (11) tüketicilerin alternatif satıcıları karşılaştırmasına ve hatta (12) ürün kullanıcılarının yorumlarına ulaşmasını mümkün hale getirmektedir. Mobil cihazların sensörlerinin ve konum bildirici özelliklerinin olması (13) tüketiciyi özel olarak takip etme imkânı da sunmaktadır.

Cep telefonları kullanılarak hedef kitlede yer alan bireylere bireysel mesajlar göndermek çok kolaylaşmıştır. Düşük maliyetli ve hızlı olduğu için üstelik hemen karşılık verme fırsatı tanıdığı için tüketiciler tarafından da tercih edilmektedir (Altunışık vd., 2017: 201). Çok sayıda mesaj alan tüketiciler için istemedikleri mesajları reddetme seçeneğini kolaylaştıran yasal yaptırımlar, mobil pazarlamadan yararlanmak isteyen pazarlama yöneticilerinin bu yöntemi kullanırken daha dikkatli davranması gerekliliğini de artırmıştır. 


\section{Beacon Teknolojisi}

Perakendecilikte mobil pazarlama uygulamalarının en önemli unsurlarından biri "beacon" iletişim teknolojisidir. Beacon teknolojisi bluetooth teknolojisi aracılığıyla çalışmakta ve küçük veri paketlerini içermektedir. Beaconlar, belirli aralıklarla müşterilerin "akıllı telefonları tarafından kabul edilecek veri paketlerini" iletmektedir. Perakendeciler bu teknolojiyi, pazarlama mesajlarını ya da mağazaya ait akıllı telefon uygulaması faaliyetlerini tetiklemek için kullanmaktadırlar. Mağaza içerisinde uygulamalardan biri bir Beacon sinyali aldığında müşteriye doğrudan bir satış tutundurma içeriği, kişiselleştirilmiş bir reklam veya etkileyici bir mesaj iletilebilmektedir. Illetilen mesaj, "sütünüzü aldınız mı?” türünde hatırlatıı bir mesaj olabilmektedir. Beacon teknolojisi, "perakendecilerle müşterileri arasındaki iletişimi artırmaya yardımcı" olmaktadır. "Yakınlık temelli (proximity-based) iletişim ve akıllı raf reklamcılı̆̆ı yöntemini kullanan perakendeciler" bu sistemle entegre olarak, alışveriş yapan müşterilerine kişiselleştirilmiş bilgiler ve indirimler sağlayabilmektedir (Gülşen ve Özdemir, 2018:120; Inman vd., 2017: 11).

\section{Sanal Gerçeklik ve Artırılmış Gerçeklik}

Sanal gerçeklik, (Virtual Reality- VR) fiilen varolmayan nesnelerin, sanki varmış gibi görülmesi ve hissedilmesi anlamını taşımaktadır. (Koçel, 2014: 504). Sanal gerçeklik teknolojisi ile üretilen bir dijital ortam, kullanıcılar tarafından gerçekmiş gibi deneyimlenebilmekte ve etkileşim kurulabilmektedir. Sanal gerçeklikte, kullanıcılar fiziksel olarak nesnelerin etrafında dolaşabilmekte ve nesnelere gerçekmiş gibi algılamalarını sağlamaktadır (Jerald, 2016: 9). Diğer bir deyişle sanal gerçeklik, "yapay ortamda insanların özgürce dolaşmalarını ve araştırma yapmalarını" sağlamaktadır (Gottlieb ve Bianchi, 2017: 18). Sanal alışveriş ortamları da bir tür sanal gerçekliktir. Bu alışverişlerde tüketiciler, kasa kuyruğu beklemeden, market arabasına dokunmadan ve araba park yeri aramadan alışveriş yapabilir. Sanal alışveriş yöntemiyle, sanal mağaza içerisindeki raflar ve reyonlar rasında geçişler sağlanarak daha hızlı alışveriş sağlanabilir (Cox vd., 2004: 273). Bu haliyle üç boyutlu ve sanal bir mağaza içinde dolaşan müşteri, gerçekte alışverişini yapabilecektir.

Artırılmış gerçeklik, (Augmented Reality- AR), sanal gerçeklikten bir adım daha öteye geçerek, kullanıcının fiziksel dünyada yapabildiği eylemlerin benzerini yapabilmesini ve dijital bilgi katarak etkileşime girebilmesini sağlamaktadır (Craig, 2013: 2). Günümüzde, internete bağlanan akıllı telefonlar ve tabletler gibi mobil cihazlardaki artış ile birlikte sanal mağaza uygulamalarındaki gelişmeler tüketicilerin alışveriş deneyimini "hem mağazada hem de çevrimiçinde" yeni boyutlar kazandıracak potansiyele sahiptir. IKEA işletmesi, evinizde mobilyanızın nasıl durduğunu görmenize yardımcı olan artırılmış gerçeklik uygulamasıyla tüketicilerine "ürünleri satınalmadan tecrübe etme fırsatı" sunmaktadır. (Rese vd., 2014: 871). Son zamanlarda, üç boyutlu (3D) bilgisayar grafikleri oluşturabilme ve sunma becerisinin gelişmesiyle birlikte "fiziksel dünyada gerçek haliyle oluşturulması mümkün olmayan görüntülerin oluşturulması" da mümkün olmuştur (Craig, 2013: 6). Çoğu artırılmış gerçeklik uygulaması, mobil cihazlar vasıtasıyla sağlanmaktadır. Akıllı gerçeklik uygulaması kullanımı, giderek "giyilebilir cihazlara veya akıllı gözlüklere doğru" kaymaktadır (Porter ve Heppelmann, 2017: 48).

Artırılmış gerçekliğin akıllı telefon veya tablet aracılığıyla "birçok tüketicinin hayatına gireceği ve yeni bilgi edinme aracı olacağı ve dolayısıyla pazarlama iletişimi için yeni fırsatlar sağlayacağı" tahmin edilmektedir (Solomon, 2017: 99). Rese vd. (2014: 870)'ne göre, "yenilikçi bir sistem tarafından sunulan ürün bilgileri, müşterilerin bilgi ihtiyaçlarını daha iyi karşılamakta ve satın alma kararlarını desteklemekte, aynı zamanda eğlenceli olarak algılanan yenilikçi bir sis- 
tem, müşterilerin duygusal ve estetik keyif gibi ihtiyaçlarını da karşılamaktadır". Porter ve Heppelmann (2017: 53)'ne göre artırılmış gerçeklik, "showroom ve ürün tanıtım konseptini yeniden tanımlayacak ve müşteri deneyimini dönüştürecektir". Müşterilerin, ürünü satın almadan ilgili ortamda görmeleri ve sanal olarak yapılan denemeler, beklentiyi karşılayıp karşılamayacağına dair kararlara yardımcı olabilecektir. Sonuç olarak artırılmış gerçeklik uygulamalarının yaygınlaşmasının, fiziksel mağaza ve showroom ihtiyacını azaltacağı öngörülebilir.

\section{Nesnelerin Interneti}

Endüstri 4.0 olarak tanımlanan anlayış, "akıllı cihazları internet aracılığıyla birbirine bağlayarak, verilerin kontrol edilmesini ve uygulama sürecinin istenilen şekilde yürütülmesini sağlamayı" kapsamaktadır. Bu anlayışın gelişme nedenlerinden birisi nesnelerin internete bağlanacak ve diğer nesnelerle haberleşecek donanıma sahip olmalarıdır.

Nesnelerin interneti (Internet of Things- IoT) oldukça geniş bir kullanım alanına sahiptir. Mevcut zamanda pek çok elektronik cihazlar, elektrikli ev aletleri, otomobiller, tıbbi cihazlar, elektrik, su ve gaz sistemleri gibi farklı türden makineler; veri toplayabilen, internete bağlanabilen ve verilerin analizini sağlayan sensörlerle donatılabilmektedir (Laudon ve Traver, 2017:152; Lindqvist ve Neumann, 2017: 26). Sayılan eşyalar internetle bağlantılı hale getirilerek "nesnelerin interneti" anlayışını getirmektedir. Son yıllarda nesnelerin interneti, değer yaratan bir yenilik olarak eğitim, iletişim, ticaret ve kamu yönetimi alanlarında kullanılmaktadır. Nesnelerin interneti, "nesnelerin bilgi alışverişini, diğer makinelerle veya insanlarla iletişim kurmalarını" sağlamaktadır (Murray vd., 2016: 341-342). Örneğin McDonald's nesnelerin internetini kullanarak hareket halinde olan müşterilerine, "Vmob durumsal analiz platformunda çalışan mobil uygulaması üzerinden yakınlarda bulunan şubesine yönlendirerek" ürün teklif (yiyecek ya da içecek) edebilmekte ya da bir promosyon sunabilmektedir (Raj ve Raman, 2017: 14).

\section{Yapay Zekô}

En basit anlamıyla yapay zekâ, insanlar tarafından geliştirilmiş ancak bağımsız karar verebilen ve kararı uygulamaya geçirebilen programlar, algoritmalar, sistemler veya makinelerdir. Yapay zekanın oluşturulabilmesi için ve işletilebilmesi için büyük veri (big data) ya ihtiyaç duyulmaktadır. Üreticiler ve perakendecilerden, temas noktalarında yer alan cihazlardan sürekli olarak veri toplanmaktadır. Bu veriler genellikle bulut tabanlı bir ortamda depolanmaktadır. Uygun kararların alınabilmesi için istatistiksel, ekonometrik modeller geliştirilmektedir. Yapay zekâ, hızla büyüyen bir çalışma alanı olarak, perakendeciliğin yeniden şekillenmesinde de etkili olmaktadır (Shankar, 2018). Tüketicilerin doğal ortamlarından alınan aramalar, sesler, sensörlerin sunduğu sıcaklık ve hız gibi diğer veriler alınarak hem işletmelere hem de tüketicilere yapılan öneriler yapay zekânın ve mobil teknolojinin birlikte kullanımı ile mümkün olmaktadır.

Yapay zekâ, perakendecilerin müşteri ihtiyaçlarını daha iyi anlamalarına ve tahmin etmelerine ve müşterilerin yaşam boyu değerini artırmak için en uygun kararları almalarına yardımcı olmaktadır. Tedarik tarafında ise tedarik zincirlerinin daha verimli hale gelmesini ve envanter yönetimi ve lojistiğin optimize edilmesini sağlamaktadır.

\section{Perakendecilik Sektöründe Teknolojiyle Bağlantılı Olarak Dinamiklerde Değişim}

Perakendeci işletmeler dağıtım sistemindeki aracılardır. Bu çalışmada ele alınan tüm değişkenler dağıtım sistemindeki aşamalardan oluşmaktadır. Örneğin tedarikçi işletmelerden mal ve hizmetleri satın alarak lojistik sitemini kullanarak tüketicilere sunma suretiyle kâr elde etmeye çalışırlar. Lojistik, hem alışta hem de satışta kullanılması bakımından etkili bir aşamadır. Satışa sunulacak mal ve hizmetlerin bir organizasyonu bulunmaktadır. Bu organizasyon perakendeci 
işletme olarak isimlendirilmektedir. Ancak, yere, büyüklüğe, ürün çeşidine ve kullanılan teknolojiye göre farklı perakendeci formatları görülebilmektedir. Dağıtımın aynı seviyesindeki başka işletmeler de perakendeci işletmeler için rakip konumuna geçmektedir. Bu nedenle tedarikçiden çıkan ve lojistik hizmetler yoluyla tüketicilere sunulacak ürünler için oluşturulacak organizasyon önemlidir. Sektördeki gelişmeler bakımından "organizasyon yapısı ve rekabet, mobil teknoloji ile nasıl değişmektedir?" sorusu cevaplanması gereken bir sorudur. Mobil teknolojiler sadece perakendeci işletmeler tarafından kullanılmamaktadır. Aynı zamanda tüketiciler tarafından kullanılan mobil teknolojiler de pazarın dinamiklerinden birini oluşturmaktadır. Tüketicilerin tutum ve davranışlarında teknolojiye bağı olarak değişimler yaşandığı bir gerçektir (Solomon, 2007: 17). Ayrıca "mobil teknoloji kullanarak değişen tüketiciye ulaştırılacak mesajların nasıl olacağı/olması gerektiği?" de cevaplanması gereken bir sorudur.

Bu çalışmada perakendeciliği etkilediği kabul edilen 4 dinamik üzerinde durulmaktadır. Bu dinamikler literatürdeki bilgiler ışığında belirlenmiştir. Bu 4 dinamiğin seçilme nedeni aşağıdaki şekilden de anlaşılabileceği gibi perakendecilik sisteminin işleyişini bütüncül olarak kapsamasındandır.

\section{Şekil 1: Perakendecilikte Temel Dinamikler}

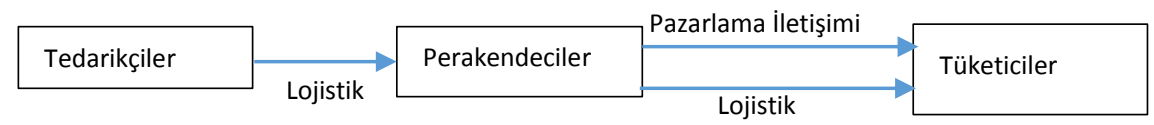

1. Tüketiciler: Deneyim, bağımsızlık, vakit azlığı, daha fazla alternetif görme isteği, kolayda ürünler için yerel marketler ancak beğenmeli ve özellikli ürünler için online araştırma ve satınalma, makineler yardımıyla insanlarla daha az ilişki içinde kendi işini gören tüketicilerin sayısındaki artışlar tüketicideki davranışın yönü hakkında ipuçları vermektedir. Bilgisayar, internet, akılı telefonlar ve sosyal medya tüketicilerde küresel boyutta hızlı bir değişim yaşanmasına neden olmaktadır.

2. Perakendeciliğin Organizasyonu ve Rekabet: Çok sayıda, farklı büyüklüklerde ve formatlarda perakendecilerin varlığı rekabeti kaçınılmaz hale getirmektedir. Rekabette kullanılacak ve avantaj sağlayacak her türlü araç perakendeciler tarafından yakından takip edilmektedir. Perakendecilik sektöründe büyük işletmelerin göze daha çok batması, küçük işletmelerin sayısındaki düşüş, görünür yerde olmayan daha küçük ve çok sayıda satıcılar, online pazar yerleri, çok küçük fiyat farklııkları, online perakendeciler hakkındaki yorumların gösterdiğine göre, hızlı ve güvenilir hizmet verme yönlü rekabet ön plana çıkmaktadır.

Klasik şubeler ve bağımsız satınalma yerini yeni bir pazar organizasyonuna bırakmış durumdadır. Pazar yerinde bulunan küçük perakendeciler, online pazarda tedarikçilerden bağlantısını yaptıkları ürünleri lojistik şirketleri aracılığıyla ulaştırmak üzere tüketicilere sunmakta, Kurumsal Kaynak Planlama (ERP) ve Müşteri i̇lişkileri Yönetimi (CRM) yazılımlarının entegrasyonu bütünlüğü ile sistem bütünlüğü sağlanmaktadır. Ürünlerin istenilen yerde bulundurulması için depolama, taşıma, ambalajlama sistemlerinin bütün olarak çalışması gerekmektedir. Bankaların, tüketicilerin, online pazar yeri sahiplerinin, perakendecilerin, lojistik işletmelerinin ve tedarikçilerin arasında işleyen ödeme sistemi organizasyonun finansal ayağını tamamlamaktadır. Çok sayıda perakendeciyi sisteme dahil ederek büyük bir zincir oluşturan entegrasyonlar, çiçek sepeti, yemek sepeti gibi birliktelikler yeni organizasyonlara örnek niteliktedir. Ayrıca yaşanan rekabette, var olmayı sürdürmek hatta daha iyiye ulaşabilmek için işletmelerin organizasyon yapılarında da değişim yaşanması zorunlu olmaktadır. 
3. Lojistik: Binlerce ürünü, yüzbinlerce tüketicisinin beğenisine sunmak ve hepsini istenilen zamanda ve yerde hazır bulundurma çalışması önemli ölçüde lojistik çalışması gerektirmektedir. Lojistikte bir dizi taşıma, yükleme, indirme, elleçleme ve depolama işlemlerinin entegrasyonu ulaştırma gerekmektedir. Lojistikte hızlı ve güvenilir ulaştırma, takip edilebilir, daha az işlem gerektiren ve işlem maliyetleri daha düşük olan ve ürüne göre esneklik sağlayan sistemler olması beklenmektedir. Örneğin İzmir'de bulunan tüketicinin siparişi sonunda Kahramanmaraş'tan dondurma tüketiciye ulaştırılabilmektedir.

4. Pazarlama iletişimi: İşletmenin tüketicilere, pazara sunulan mal ve hizmetlerle ilgili mesajları iletmeleri pazarlama iletişimi olarak kabul edilmektedir. Tüketicilerin kararlarında ve davranışlarında etkili olabilecek mesajlar reklam, kişisel satış, satış geliştirme, halkla ilişkiler gibi yöntemler kullanılarak tüketicilere ulaştırılmakta ve bu yolla tüketiciler etkilenmeye çalışılmaktadır. Mobil teknoloji, kabaca söylemek gerekirse tüketicilere bireysel olarak ulaşma ve mesajı kişiselleştirme imkânı sunmaktadır. Aslında bu kişiselleştirme tüketici davranışlarında çok sayıda değişime de neden olma potansiyeline sahiptir.

Dinamiklerin ele alınmasında ve açıklanmasında mobil iletişim teknolojisi üzerinde daha çok durulmaktadır. Çünkü mobil iletişim teknolojisindeki değişimler, pek çok alanda olduğu gibi perakendecilikte de önemli değişikliklere neden olma potansiyeli taşımaktadır.

Mobil iletişimin diğer değişkenler üzerinden de perakendeciliği etkileme potansiyeli bulunmaktadır. Bu durum mobil iletişim teknolojisinin dolaylı olarak da perakendeciliği değiştirebilme gücü olduğunu göstermektedir. Böylece perakendeciliği değişime zorlayan dinamikler, resmi tamamlayacak şekilde ele alınmaya çalışılmıştır.

\subsection{Tüketicide Değişim}

Mobil pazarlama, perakendecilik sektöründe giderek daha çok önem kazanmaktadır. Mobil ortam ve cihazların oluşturduğu fırsatlarla birlikte, tüketici kendisinin nerede olduğunu önemsemekte, alış veriş için harcayacağı zaman azalmakta, nereden alışveriş yaptığına daha az dikkat etmektedir. Dolayısıyla mobil pazarlama, perakendecilik anlayışını ve uygulamalarını değiştirme yönünde bir gücü barındırmaktadır. Perakendeciler artık tüketici ortamına mobil cihazlar aracıIığıyla girebilmektedir. Başka bir ifade ile tüketiciler perakendeci mağazaları bulundukları yerden, günün herhangi bir saatinde, online olarak ziyaret ederek alışveriş yapabilmektedir. Çünkü mobil cihazlar tüketici ile birlikte dolaşmakta ve dolayısıyla, perakendeciler her zaman ve her yerde ulaşılabilir olmaktadır (Shankar vd., 2010: 111-112).

Samuely (2018)'in ifadesine göre yeni müşteriler, detaylı ürün bilgisi, yeni teklifler, fırsatlar, fiyat karşılaştırma, ürün hakkındaki kullanıcı görüşleri, tamamlayıcı ve alternatif ürünler hakkındaki verileri kullanarak alışveriş yapma eğilimindedirler. Fiziksel mağazalar, mobil pazarlama uygulamaları ile müşteri deneyimlerini geliştirerek online mağazalarla rekabet etmeye çalışmaktadır. Merkezi Amerika Birleşik Devletleri'nde olan Minyard Sun Fresh Market, Target, Kroger ve Carrefour gibi uluslararası perakendeci kuruluşlar mağaza içi mobil pazarlama uygulamalarına ağırlık vermişlerdir. Bu kapsamda yapılan aktivitelere örnek olarak; hoşgeldin mesajları, sosyal paylaşım, tamamlayıcı ürünler, haftalık aktüel ürünler kataloğu, yeni teklifler, fırsat ürünler, ürün bilgileri, ürün incelemeleri, mağaza içindeki ürün konumu, mağaza haritası, ürün stok durumu, alternatif ürünler, kişiselleştirilmiş ürün teklifleri, puan toplama, dijital kupon, alışveriş listesi, e-ticaret/POS ödeme ve isteğe bağlı mağaza içi ya da eve teslim uygulamaları verilebilir. 
Kotler ve Armstrong (2018: 525-526)'un ifadesine göre mobil pazarlama uygulamaları; mobil reklamlar, kupon, metin mesajları, mobil uygulamalar ve mobil web türünde birçok araç vasıtasıyla alışveriş sürecinde hareket halindeki tüketicileri etkilemek mümkündür. Pazarlama faaliyeti yapan pek çok kuruluş kendilerine ait web sitelerini akıllı telefonlara uygun hale getirmiştir. Bazıları da müşterilerini markalarıyla buluşturmak ve alışveriş yapmaları için etkileyici, faydalı veya eğlenceli mobil uygulamalar geliştirmiştir. Mobil pazarlama, gelecek için hem büyük umutlar hem de birçok zorluk sunmaktadır.

Rekabetçi perakendecilik ortamında hayatta kalmak için sadece düşük fiyat politikası uygulamak ve yenilikçi ürünler satmak yeterli değildir, daha fazlası gereklidir. Müşteri deneyimi, müşterinin alışveriş, mal veya hizmetle etkileşime girdiği an itibariyle temas kurduğu bütün aşamaları içermektedir. Verhoef vd. (2009: 31)'ne göre üstün müşteri deneyimi yaratmak bugünün perakendecilik pazarının ana hedeflerinden biri olarak görülmektedir. Dünya genelindeki perakendeciler, müşteri deneyimi yönetimi kavramını benimsemişler ve pek çoğu bu kavramı misyonlarıyla ilişkilendirmişlerdir.

\subsection{Perakendecilik Organizasyonunda ve Rekabette Değişim}

Dağıtım sürecinin en son aşaması olan perakendecilik, nihai tüketicilere kişisel ve ailevi ihtiyaçları için kullanılmak üzere satışı yapılan mal ve hizmetlere değer katan ticari faaliyetler dizisidir (Perrault vd., 2017: 308; Levy ve Weitz, 2012: 6; Dunne vd., 2011: 4; Berman ve Evans, 2007: 115). Perakendeci, satışlarını temel olarak perakende olarak gerçekleştiren ticari bir kuruluştur. Ancak mağazası olmadan perakendecilik yapan mağazasız perakendeciler de eskiden beri bulunmaktadır. Perakendecilik, mal ve hizmetlerin kişisel tüketim amacına yönelik olarak; posta yoluyla, telefonla, otomatik makinede, internet üzerinden, bir mağazada, sokakta veya tüketicinin evinde satışının yapılmasıdır (Kotler ve Keller, 2016: 549). Diğer bir açıdan perakendecilik, nihai tüketicilerin arzuladığı mal ve hizmetleri, uygun zamanda ve uygun yerde ve uygun miktarda sunmayı kapsamaktadır. (Samson, 1969: 15). Bunlar kısaca pazarlamanın mekân, şekil, zaman ve mülkiyet faydası sunması anlamına gelmektedir. Aynı zamanda perakendecilik, bir toplumdaki ekonomik etkinliklerin önemli bir bölümünün tüketiciler tarafından günlük yaşamda görünen yüzüdür (Tek ve Özgül, 2013: 530).

Perakendecilikte başarı sağlamak için mağazacılık, müşteri tatmini, ilişki pazarlaması, müşteri sadakati gibi kavramlar üzerinde durmak ve bunları bilinçli olarak uygulamaya yansıtmak gerekmektedir (Özdemir, 2008: 3). Perakendecilikte bilgi işlem teknolojisinin kullanılması, sektöre özel yazılımların varlığı ve mobil cihazlar bu beklentileri karşılamaya yardımcı olmaktadır.

Perakendecilik sektörüne giriş de çıkış da sanayi sektörüne göre kolaydır. Bu yüzden perakendeci işletme başarılı olmak için, bir taraftan tüketicilere mal ve hizmet sunmada tatmin edici olmak; diğer taraftan, üretici veya toptancılarla sağlam bir ilişki kurmak zorundadır. İşte bu iki rol, hem perakendeciliğin ekonomik açıdan varoluş nedeni, hem de başarısının anahtarıdır (Mucuk, 2007: 277). Perakendecilerin temel görevi nihai tüketiciye ihtiyacı olan mal ve hizmetleri ulaştırmak için uygun bir pazarlama karması oluşturmaktır. Çünkü tüketiciler, ihtiyaç duydukları malların uygun zamanda, uygun yerde, uygun miktarda ve uygun fiyatta perakendeciler tarafından sağlanmasını beklemektedirler. Perakendeciler bu şartları yerine getirebildikleri ölçüde başarılı oldukları kabul edilmektedir (Varinli, 2012: 5). Online mağazalar ve bu mağazalara mobil erişim imkânının varlığı, perakendeciler ile tüketiciler arasındaki mesafeyi kısaltmakta ve perakendecilerin başarısında katkı sunmaktadır. 
Mobil teknoloji akıllı sistemler ve yapay zekâ ile birlikte perakendecilikte insanlardan oluşan örgüt yapısı daha az sayıda insan tarafından oluşturulmaktadır. Ayrıca oluşturulan organizasyon, "insana bağlı" olmaktan çıkmakta ve daha çok otomasyona bağlı hale gelmektedir. Otomasyonun gerçek zamanlı olarak takip edilmesi ise büyük oranda mobil teknolojiye bağlı olmaktadır. Çünkü perakendecilik sistemi içerisinde, stok takibinden, mal ve hizmetlerin tedarikine, raflara yerleştirilmesinden, tüketicilere ulaştırılması aşamasına kadar çok sayıdaki aşama bulunmaktadır. Mobil teknoloji, çok sayıda küçük şubeden oluşan, birbirinden uzak ve ara sokaklara kadar dağılmış perakendeci şubelerin bir merkezden yönetilmesine imkân vermektedir. Böylece şubeler üzerindeki yöneticilerin sayısı azalmakta; organizasyon içindeki hiyerarşi kademelerinin sayısında da bir azalma getirmektedir. Bunun nedeni online olarak kontrol edilebilen çok sayıda mağazanın varlığının olmasıdır.

Sanal ve artırılmış gerçeklik ve nesnelerin internete sahip olmaları mağazaların içinde yapılacak kaynakların organizasyonu değiştirme potansiyeli taşımaktadır. Yukarıda örnekleri verildiği gibi alış veriş ortamlarını sanallaştırmak ya da ürünün kendi oturma odanızda nasıl duracağını test etme imkânını veren artırılmış gerçeklik uygulamaları, mağazalarda yeni alanlar, yeni istihdam alanları oluşturma potansiyeli taşımaktadır. Başka bir ifadeyle perakendecilikteki fiziksel ortam ve mekânsal kullanımı sanal gereçeklik ve artırılmış gerçeklik uygulamalarına uyarlanacak şekilde değişmektedir. Bunlara bağlı olarak da çalışan insan kompozisyonu ve ilişkiler de değişmektedir. Çalışan sayısının azalmakla birlikte niteliklerinin ve farklı işlerde teknik beceriler sahibi insanların perakendecilik sektöründe çalışmaları sözkonusu olabilir.

Mobil pazarlama yöntemleri kullanan işletmeler arasındaki rekabet, daha çok "satış sonrası hizmetler konusu ve fiyat" konusuna dayanmaktadır. Satış sonrası verilecek hizmetler ve fiyat, rekabette işletmeyi ön plana çıkarabilmektedir. Mobil pazarlamayı kullanmayan işletmeler ile kullanan işletmeler arasındaki rekabette ise mobil pazarlama, çok sayıda rekabet avantajı sağlamaktadır. Örneğin müşteri ile doğrudan iletişim kuran, ürünlerin teslim edilmesinin her aşamasında ürünü takip edebilen ve bu bilgiyi müşteri 24 saat sürekli paylaşabilen perakendeciler mobil pazarlamaya başvurmayan işletmelere göre tüketiciler tarafından daha çok tercih edilmektedir. Kısacası müşteri memnuniyeti, geri dönüşü, müşteri takibi, ürün takibi, lojistik organizasyonları, pazarlama iletişiminin daha etkin kullanılması gibi sonuçlar doğuran mobil pazarlama, kısa sürede asgari hizmet standardı haline gelmektedir. Asgari hizmet standardını sağlayamayan işletmeler tüketiciler tarafından terk edilmektedir. Dolayısıyla mobil pazarlama rekabetin yönünü, müşteri yönlü, hızlı satış, daha çok bilgi sahibi olma ve bilgiyi etkin kullanma, satış sonrası hizmetler ve fiyat rekabeti olarak değiştirmektedir. Ayrıca tüketicilere sunulan gerçek zamanlı bilgiler, tüketicinin alternatifler arasındaki seçiminde etkili olmaktadır

\subsection{Lojistikte Değişim}

Perakendecilik tüketicilere hizmet vermeye çalışırken arka planda çalışmakta olan devasa bir lojistik hizmeti bulunmaktadır. Dünyanın en uzak noktalarındaki üretim noktalarından alınan ürün binlerce noktaya dağıtılırken, ürün maliyetleri üzerinde çok etkili olmamasına ve ürünün değer kaybetmemesine dikkat edilmektedir.

Perakendecilerin raflarında sürekli olarak yer alan ürünlerin raflarda boşalması sadece raf ile depo arasındaki bir işlem eksikliği değildir. Binlerce şubesi olan perakendeci hergün tüm mağazaların boşalma hızını bilmeli ve ona göre her şubeye ait ürünleri sevk için hazırlamalı, maliyeti artırmadan mağazaların raflarında ürünleri tüketicilerine sunabilmelidir. İşte tüm bunlar 
perakendecilerin başarısında etkili olan lojistik operasyonlardır. Büyük perkakendecilerin lojistik operasyonlarının merkezlerinde optimizasyon problemlerini çözmek üzere geliştirilmiş yazılımlar ve buna bağlı olan akıllı sistemler kullanılmaktadır.

Lojistik operasyonlarda kullanılan mobil teknolojiler RFID, GPS tabanlı takip sistemleri, internet tabanlı networkler, mağazalar arası iletişimi sağladığı gibi bir merkezden tüm mağazalardaki operasyonları gözleyerek değerlendirme fırsatı sunmaktadır.

Araç takip ve izleme sistemleri, mobil terminaller ve otomasyon uygulamaları ile mağazalara sevkedilen ürünlerin miktarı ve satışların anında bilgi işlem teknolojileri yoluyla takibinin mümkün olması perakendeci yönetimlerine büyük kolaylıklar sunmaktadır.

Lojistik sektörü fiziki olarak var olan perakendecilerden daha çok online perakendecilerin işine yaramaktadır. Fiziki olarak bir mağazası olsun olmasın, online olarak tüketicilerine ürünleri sunan işletmeler, arka planda tedarikçiler ile yaptıkları işbirlikleri ve lojistik hizmetleri sayesinde işlerini sürdürebilmektedir.

Online olarak satın alınan bir ürünün perakendeci tarafından yapılan "sipariş işleme, tedarik, mal kabul, paketleme, yükleme, taşıma, yerel dağıtım, iade" gibi aşamaları, perakendeci işletmelerin kullandıkları bulut tabanlı yazılımlar sayesinde yöneticiler tarafından (bir kısmı tüketiciler için de geçerli ) gözlenebilir hale gelmiştir. Bundan dolayı eskiden sadece tedarik olan süreç artık tedarik zinciri olarak yönetilebilir bir hal almıştır.

Mal ya da hizmet satan işletmelerden mobil teknoloji kullanarak satın almalar yapan tüketicilerin bazı işlemleri (sipariş kontrol, bilgilendirme gibi), ürünü satan işletmeden bağımsız farklı olarak mobil teknoloji kullanan başka işletmeler tarafından verilebilmektedir. API (Application Programming Interface) adı verilen bu sistem sayesinde depo yönetim sistemlerine entegre edilebilen e-ticaret sistemleri, ERP sistemleri mümkün hale gelmiştir. API, iş ortaklarıyla esnek ve uyarlanabilir bağlantılar kurmak suretiyle kullanıcılarına değer katmaktadır (Mulesoft, 2018).

Perakendecilik sektöründe özellikle yaşı ve engelli tüketiciler, ulaşımı nispeten zor yerlerdeki tüketiciler için uzaktan kontrol edilebilen insansız hava taşıtları (Drone) yardımıyla mal ve hizmet sunuşu yapmak mümkündür. Kapsamı daha küçük olmak üzere engelli ve yaşlı tüketicilere istedikleri ürünleri evlerine teslim eden, yerde hareket eden robotların kullanılması da mümkündür.

Bazı hastanelerde kullanılan Pnömatik Tüp Taşıma sistemi de mobil teknoloji ile entegre çaIışabilmektedir. Hastanenin istenilen tüm mekânlarında yükleme ve çıkış noktaları olan, gönderici, gideceği yer tanımlandıktan sonra birkaç saniye içinde hedefine ulaşan "kargo"ları taşıyan sistemler kullanılmaktadır (Ergür, 2015). Bu sistemlerin bir benzerinin perakendeciler ile tüketicilerin evleri arasında kurulması durumunda alışverişin şekli ve niteliği değişebilecektir. Şehirlerarasında benzer teknoloji ile insan taşımak (Hyperloop) için altyapının oluşturulması, bu teknolojinin daha ucuza ve yaygın şekilde kullanılarak evlere ürün dağıtımını da mümkün hale getirebilir. Elektrik, su, gaz, internet dağıtımından sonra zaten var olan ve kullanılan bu teknolojinin ürün dağıtımında kullanılıp kullanılmaması kararı, perakendeciler için sadece kazanç getirip getirmeyeceği hesabına bağlıdır.

Yakın zamana kadar kargo şirketlerine teslim edilen ürünlerin tüketicilere ulaşması bekleniyordu. İnternet ve mobil teknolojiler sayesinde artık taşıma şirketlerine teslim edilen ürünlerin her aşamada takip edilmesini sağlayan ve karşılıklı olarak iletişimi mümkün hale getiren yeni bir lojistik anlayışı olan "dördüncü parti lojistik" (4PL) sistemi gelişmiştir. Kumar (2008:206), dördüncü parti lojistik sistemini, herhangi bir durumda en verimli tedarik zinciri çözümüne karar 
vermek için bilgilerin toplanmasından, koordinasyonundan ve yönetiminden sorumlu işletme varlığı olarak ifade etmiştir. Keskin (2018: 72)'nin ifadesine göre dördüncü parti lojistik tedarikçileri kapsamlı tedarik zinciri çözümleri sunmak için kendi organizasyonunun kaynaklarını, yeteneklerini ve teknolojisini, tamamlayacı hizmet sağlayıcılarla bir araya getiren ve yöneten bütünleştiricilerdir. Bir diğer ifadesiyle lojistik sektörde bilgi ve ürün akışı konusunda danışmanlık hizmeti veren firmalar olarak tanımlamıştır.

Lojistik operasyonların tamamı, mobil iletişim teknolojisi sayesinde gerçek zamanlı olarak takip edilebilmektedir. Üstelik ürünlerin tedarik zincirinin hangi aşamasında olduğunu bilgilendiren mesajlar yoluyla istenildiği anda müdahale esnekliği sağlamaktadır. Ayrıca dijital olarak tutulan kayıtlar ürünlerin ayak izlerini oluşturmaktadır. Dijital izler sayesinde süreçte ya da süreçten sonra denetim imkânı sunmaktadır.

Mobil tekonolojilerin kullanımı büyük işletmeler tarafından kullanılmaktadır. Bu durum küçük işletmelerin yeni duruma uyum sağlayamamaları durumunda rekabete yenik düşecekleri anlamına gelmektedir. Mobil teknolojiler ile tedarik ve teslim sürelerinde kısalmalar, perakendecilere rekabet avantajı sağlamaktadır.

\subsubsection{Lojistik 4.0}

Lojistik sektörünün Endüstri 4.0 ihtiyaçlarına göre değer zincirine entegrasyonunu güçlendirecek uygulamalar hızla gelişmektedir. Aslında süreçleri otomatik olarak kontrol eden bilgisayar destekli sistemler sayesinde birçok taşımacılık süreci kontrol edilmektedir. Bunlara ek olarak otonom çalışan sürücüsüz TIR'lar, kaptansız gemiler, pilotsuz uçaklar, drone'larla teslimatlar, bulut teknolojisi, süreçlerin dijital platformlara taşınması da son zamanlarda çok irdelenen ve tartışılan konulardandır. Tüm bunlar lojistik sektöründe yeni iş yapma süreçlerinin, yani Lojistik 4.0'ın oluşturulmasını, geliştirilmesini, sanayi ve ticaretle bütünleştirilmesini zorunlu kılmaktadır (Özdemir, 2017). Aslında lojistikte dönüşümsel değişim gücüne sahip bütün bu gelişmeler bir taraftan yenilikçi mobil teknolojilerdeki yazılım ve donanımın hızla gelişmesi, diğer taraftan nesnelerin internet üzerinden izlenmelerini ve kontrol edilmelerini sağlayan fiziksel nesnelere yerleşik sensörler ve veri iletişim teknolojilerinin sağladığı söylenebilir.

Lojistikte nesnelerin interneti (IoT) çeşitli fiziksel nesneleri bir tedarik zinciri boyunca bağlayabilir ve otomatik sistemleri kullanarak üretilen verileri gerçek zamanlı olarak analiz edebilir. Dolayısıyla sadece gönderilerin bulunduğu yerleri değil aynı zamanda gönderilerin yolculuğunun sıcaklık, yol durumu ve trafik gibi dinamiklerini de analiz ederek araç rota üzerinde iken daha önce mümkün olmayan esneklikte kritik kararların alınmasını kolaylaştıracak şartları sağlayabilir. Diğer bir deyişle lojistik maliyetlerini optimizasyon esaslı olarak düşürülmesini sağlayabilir (MÜSIAD, 2017: 74). Nesnelerin interneti (IoT)'nin potansiyel faydaları, depolama, nakliye ve son kilometre teslimatı gibi alanlar dahil olmak üzere her türlü lojistik faaliyet boyunca yayılmaktadır. Örneğin, ürünleri taşımak için bir depo ortamında kullanılan bir forklift, artık mobil teknolojiler kullanılarak internet üzerinden erişilen değerli bilgilerin kaynağı olabilir. Bu forklift, kendisi ve içinde bulunduğu çevre hakkında çeşitli operasyonel verileri kablosuz bağlantı, veri deposu ve sensörler aracılığıyla sağlayabilir (Murphy ve Knemeyer, 2018: 53 ).

\subsection{Pazarlama İletişiminde Değişim}

Mobil pazarlama bağlamında birçok perakendeci kuruluş, gelişen teknolojik yenilikler aracıIığıyla müşterilerine akıllı telefon uygulamaları üzerinden mağaza içi yeni deneyimler ve yenilikçi çözümler sunabilmektedir. Inman ve Nikolova (2017: 12)'nın ifadesine göre müşterilerin alışve- 
riş sürecinde akıllı telefon uygulaması ile taranan ürünleri kasada tekrar taramaya gerek duymadan ve alışveriş tutarını aynı uygulama üzerinden ödeyerek mağazadan ayrılabilmeleri mümkündür. Akıllı telefon kullanılarak yapılan hızlı ve otonom alışveriş, deneyime ve zamana duyarlı olan müşteriler için çekici olabilmektedir.

İnternet üzerinden satış yapan ve perakendeci olarak bilinen tüm kuruluşlar aynı nitelikte hizmet sunmamaktadır. Bazı perakendeciler, belirli alanlarda uzmanlaşarak satış yaparken (oto yedek parça, kitap, vs); bazıları ise gerçekte bir ürün sunmaktan ziyade satıcılarla alıcıların buluştuğu bir platform (pazar yeri) hizmeti (amazon, n11, hepsiburada vs) sunmakta, bazıları ise ikinci el ürünler sunmaktadır. Hem fiziksel olarak mağaza işleterek perakendecilik yapan ve aynı zamanda web sayfası ve akıllı telefonlara yönelik uygulamalar geliştirerek müşterilerine etkin bir şekilde ulaşmaya çalışan perakendeciler (örneğin Migros) de bulunmaktadır.

Uygulamaların sanal olması ya da olmaması tüm perakendecilerin akıllı telefonlara yönelik uygulamaları giderek daha çok kullanıyor olmaları gerçeğini değiştirmemektedir. Web sayfaları ve akıllı telefonlar için geliştirilmiş uygulamalar farklı şekillerde müşteriye ulaşmak için yeniliklere sahne olmaktadır. Şaşırtıcı bir hızla çeşitleri ve sayıları artan mobil pazarlama iletişim uygulamaları tüketicileri etkilemek amacıyla farklı formatlarda sunulmaktadır. Aşağıdaki tabloda mobil iletişim mesajlarının zaman içinde geçirdiği değişimler gösterilmiştir. Bu değişimleri bütün olarak görmek, değişimin yönünün ve hızının gelecekte ne olacağı hakkında tahminde bulunmaya yardımcı olabilir.

Tablo 1: Mobil iletişim ve Mesajlardaki Değişim

\begin{tabular}{|c|c|}
\hline Mobil Pazarlama İletişim Kanalı & Pazarlamada Kullanılması \\
\hline SMS & $\begin{array}{l}\text { Kısa mesaj hizmeti (Short Message Service) yönteminde özellikle izinli } \\
\text { pazarlama bağlamında mağazalar tarafından özel gün indirimi, } \\
\text { kişiselleştirilmiş pazarlama mesajları şeklinde sıkça kullanılmaktadır. }\end{array}$ \\
\hline $\begin{array}{l}\text { MMS- Çoklu Ortam Mesajlaşma } \\
\text { Servisi }\end{array}$ & $\begin{array}{l}\text { Çoklu ortam mesajlaşma (Multimedia Messaging Service), bu yöntemde, } \\
\text { kısa mesaj servisinden farklı olarak gönderilecek mesajlara resim, video ve } \\
\text { ses gibi çoklu ortam dosyaları da eklenebilmektedir. }\end{array}$ \\
\hline E-Mail & $\begin{array}{l}\text { Akıllı telefonların gelişmesiyle birlikte elektronik posta üzerinden } \\
\text { kişiselleştirilmiş pazarlama mesajları sunulmaktadır. }\end{array}$ \\
\hline IVR- İnteraktif Sesli Yanıt & $\begin{array}{l}\text { Müşteriler için önceden kaydedilmiş sesli bir mesajın otomatik bir sistem } \\
\text { üzerinden telefon tuşlarının da kullanılmasına olanak veren interaktif çift } \\
\text { yönlü iletişim yöntemidir. Otomatik müşteri hizmetlerinde sıkça } \\
\text { kullanılmaktadır. }\end{array}$ \\
\hline Sosyal Medya İçerikleri & $\begin{array}{l}\text { İçerik, özellikle sosyal medyanın gelişmesiyle birlikte içerik pazarlamasının } \\
\text { önemi daha da artmıştır. Hedef kitlede ilgi uyandıracak içerikler } \\
\text { paylaşılabilir. Örneğin kampanya, kupon, indirim vd. }\end{array}$ \\
\hline Mobil Web & $\begin{array}{l}\text { Akıllı ve geniş ekranlı telefonlarda sunulan mobil telefon uygulamalarıyla } \\
\text { müşterilerine her zaman ve her yerde alışveriş yapma fırsatı sağlar. } \\
\text { Müşterilerin ilgisini uyandıracak içerik ve kampanya benzeri pazarlama } \\
\text { mesajları da paylaşılabilir. }\end{array}$ \\
\hline Yakınlık/konum Temelli İletişim & $\begin{array}{l}\text { Bluetooth, Wi-Fi ve Beacon, teknolojisinin yaygınlaşması ve internete } \\
\text { erişebilirliğinin artması ile birlikte yakınlık ve konum bazlı pazarlama } \\
\text { yöntemlerinin uygulanmasını sağlamıştır. Bu yöntemde mesajların } \\
\text { veritabanından da faydalanılarak müşteri özelliklerine ve satınalma } \\
\text { davranışlarına göre kişiselleştirilerek sunulmasına olanak vermektedir. }\end{array}$ \\
\hline Mobil Uygulamalar & $\begin{array}{l}\text { Mobil Uygulamalar, çok amaçlı kullanılan mobil uygulamalar perakendecilik } \\
\text { sektöründe mobil alışveriş, ödeme, pazarlama amaçlı oldukça yaygın bir } \\
\text { şekilde kullanılmaktadır. }\end{array}$ \\
\hline
\end{tabular}




\begin{tabular}{ll}
\hline $\begin{array}{l}\text { Yakın Alan İletişimi (Near Field } \\
\text { Communication- NFC) }\end{array}$ & $\begin{array}{l}\text { NFC, } 10 \mathrm{~cm} \text { 'ye kadar olan mesafelerde veri aktarımına (örneğin, kredi kartı } \\
\text { bilgisini bir akıllı telefondan POS'a) izin veren kablosuz bir iletişim } \\
\text { teknolojisidir (Ozturk, vd., 2017: 2028). }\end{array}$ \\
\hline Uygulamalarda yer alan reklamlar & $\begin{array}{l}\text { Akıllı telefonlarda kullanılan eklentilerde yer alan ve uygulama sahibine bir } \\
\text { bedel ödeyerek uygulmada yer bulan reklamlar tüketicilere ulaşmaktadır. }\end{array}$ \\
\hline Kişiselleştirilmiş reklamlar & $\begin{array}{l}\text { Hakkında arama motorlarını kullanarak arama yaptığımız ürünler } \\
\text { kişiselleştirilmiş mesajlarla belirli süreler teklifler sunabilmektedir. }\end{array}$ \\
\hline Sosyal Medya Reklamları & $\begin{array}{l}\text { Akıllı telefonlarda bulunan ve milyarlarca kullanıcısı bulunan sosyal medya } \\
\text { uygulamaları başlı başına bir reklam mecrası olarak kullanılmaktadır. }\end{array}$ \\
\hline Küresel Konum temelli mesajlar & $\begin{array}{l}\text { Akıllı telefonlara hizmet veren baz istasyonlardan, ya da internet kullanımı } \\
\text { yoluyla etkin olan konum bilgileri kullanılarak oluşturulan özel mesajlar. }\end{array}$ \\
\hline
\end{tabular}

Kaynak: Becker ve Arnold, 2010: 23'den uyarlanarak araştırmacılar tarafından geliştirilmiştir.

Tablo 1, perakendecilikte en yaygın kullanılan mobil pazarlama iletişimi kanallarını ve yeni pazarlama kurgularını göstermektedir. Tablonun geneli incelendiğinde pazarlama yöneticileri için pek çok farklı mobil iletişim kanalının ve yeni pazarlama kurgularının mümkün olduğu söylenebilir. Bu kapsamda perakendeci kuruluşlar, mobil e-mail, mobil mesaj, mobil reklam, mobil kupon, kişiselleştirilmiş içerik, kişiselleştirilmiş ürün teklifleri, fırsat ürünler, haftalık aktüel ürünleri, mobil müşteri servisi, mobil sosyal medya yönetimi, isteğe bağı ı mağaza içi ya da doğrudan eve teslimat gibi uygulamalarla müşteri memnuniyeti ve satış tutundurma stratejisi geliştirebilirler.

Akıllı telefonlara yönlendirilen mesajların zaman içinde basitten karmaşığa doğru, sade mesajdan zengin içerikli mesaja doğru dönüştüğü ifade edilebilir. Ayrıca mesajların ulaştığı hedef kitlenin gittikçe daha isabetli olacak şekilde özelleştiği, hatta bireysel ilgi alanları bile belirlenmiş tüketicilere özel mesajlar geliştirildiği ve iletildiği söylenebilir. Hem yakınlık hem de küresel konum temelli mesajlar davranış ile konum arasındaki ilişkiden hareketle sadece hedef pazarda yer alan kişilere mesaj verme imkânı sunmaktadır. Akıllı telefonların iletişim gücü sayesinde tüketiclerin daha hızlı tepki (kabulü durumunda alışveriş için harekete geçerek ya da mesaj içeriğini veya kendisini reddederek) verebilmektedir.

Ayrıca perakendeciler tarafından sunulan teklifler, iletilen mesajlar ya da müşteri deneyimi akıllı telefon kulanılarak sosyal medya ortamlarında da paylaşılması mümkün hale getirilerek ağızdan ağıza iletişim (WOM) etkisi artırılmış olmaktadır.

\section{Sonuç}

Geleneksel perakendecilik, fiilen ve fiziki olarak mağaza ile temas eden tüketicilere dayanmaktadır. Bu durum perakendeci işletmenin lokasyonunu en önemli rekabet avantajı (ya da dezavantajı) kaynağı haline getirmektedir. Mobil pazarlama bu anlayışı değiştirmektedir. Artık perakendecilerin tüketicilere yakın yerlerde kurularak avantaj sağlayacağı düşüncesi, mobil iletişimle birlikte değişime uğramaktadır. Teknolojik yenilikler perakendecilerin iş yapma biçimini gelenekselden moderne doğru dönüştürmektedir. Örneğin sabit bir yere bağlı olma terkedilmekte hareket halindeyken ve evdeyken alışveriş yapılabilmektedir. Klasik ödeme ve teslim biçimlerinin terkedilmesi sonucu mağazaların fiziksel varlığının gerekliliği azalmaktadır. Giderek fizikel mekanlara bağlı olmadan var olan perakendecilerin varlığı artmaktadır. Ancak perakendecilerin fiziksel olarak varlıklarının azalması lojistik ve organize çalışma ihtiyaçlarını artırmaktadır.

Müşteriye özel değer yaratma, hızlı, çok sayıda alternatifin değerlendirilebileceği bir sistem geliştirmek eskiye göre daha mümkün ve kolaydır. Birçok ürün, artırılmış gerçeklik ile sanal denemeler sonucu tüketicilerin beğenisini kazanma potansiyeli kazanmaktadır. 
Tüketicilerin GDO, organik ürün, helal ürün hassasiyetleri bulunmaktadır. Daha büyük ve entegre oganizasyonlar tüketicilerin hassasiyetlerini daha iyi karşılama potansiyeline sahiptirler. Elektronik etiketler üzerindeki bilgilendirmeler ve bunların kontrolü bilişim sistemleri üzerinden olunca daha etkili ve tatmin edici hale gelmektedir. Ürün üzerindeki karekodun okutulmasıyla ürün hakkında pek çok bilgi edinilebilmektedir. Bilgilerin dijital olarak işlendiği sistemde ürünün teknolojik olarak bıraktığı ayak izlerinin takip edilmesi daha kolaylaşmıştır. Böylece ürün güvenliği artarken, sürecin takip edilebilmesi nedeniyle şeffaflık sağlanmış olmaktadır. Bu durum özellikle gıda ürünlerinde israfı önleyerek sürdürülebilir bir gelecek hazırlamak anlamına da gelebilmektedir.

Bugün, perakendecilik sektöründe çalışan insanların çoğu satış işlerinde çalışırken; yakın gelecekte teknik bilgisi ve becerisi yüksek kişilere sektörde daha çok ihtiyaç duyulacağı tahmin edilebilir. Onbinlerce çalışanı olan Wal-mart isimli perakendeci, personelinin üniversite okumasını sağlamaya çalışmakta ve teşvik etmek amacıyla üniversitelerle işbirliği yaparak günde 1 dolara üniversite eğitimi almalarına yardımcı olmaktadır (Friedman, 2018). Başka bir ifadeyle mobil teknoloji, istihdamın yapısını ve sayısını değiştirme potansiyeli taşımaktadır.

Beacon teknolojisi, mobil telefonlardaki sensörler yardımıyla toplanan diğer bilgilerle birlikte kullanıldığında daha etkin bir pazar bölümlendirme yapmak mümkündür. Müşterilerin kendini özel hissedecek teklifler duyması bundan sonra daha muhtemeldir. Nitekim Alibaba yaşlı müşterileri için özel uygulamalar sunmaktadır.

Yapay zekaya sahip aynalar ve beden ölçülerinizi verdiğinizde giyebileceğiniz elbiselerin üzerinizde nasıl duracağını gösteren yazılımlar, perakendecilikte dokunarak seçeceğiniz ürünleri dokunmadan ve kolaylıkla deneyebilmenizi sağlayacak artırılmış gerçeklik uygulamalarıdır. Bu uygulamalar şimdilik sınırlı sayıda perakendeci tarafından kullanılıyor olsa da yakın gelecekte yaygınlaşması öngörülebilir.

Ürün ve mesaj kişiselleştirme zaten uygulanmaktadır. Bu durum mikropazarlama ugulamalarının yaygınlaşmasına neden olma potansiyeli sağlamaktadır. Mikropazarlama eğer maliyetler yükseltilmeden yapılabilirse tüketicilerde daha yüksek memnuniyet sağlayacaktır.

Perakendecilik alanında rekabetin yönü giderek hem daha "büyük olmaya" hem de "teknolojiyi (internet, mobil vs) iyi kullanmaya" bağlı olmaktadır. Başka bir ifade ile perakendecilik eperakendeciliğe dönüşme potansiyeli taşımaktadır. Bu trendin bir sonucu olarak küçük ve çok sayıda perakendeci ya dükkanı kapatacaklar, ya online satış yöntemini kullanarak pazarlarını büyütmek durumunda kalacaklardır. Her iki durumda da gelecekte daha büyük ve online perakendecilerin pazara hakim olacağını söylemek mümkündür.

Online olarak daha çok ve kapsamlı hizmet sunan perakendeciliğin önceliği "müşteriler" olduğu için, yaşanan gelişmeler müşterilerin yaşanan değişimden karlı çıkması anlamına gelmektedir. Robot alışveriş asistanları, hem tüketicilere yardımcı olabilecek hem de raf yönetimine yardımcı olmak suretiyle hem mağaza içinde hem de dışarıdaki dağıtım sürecinde giderek daha çok rol üstlenmektedir. Alışverişe yardımcı olan drone, robot ve drone teknolojileri, ürünlere ulaşmayı kolaylaştırabilecektir. İnternetin evlerin her odasına ulaştığı gibi, "perakendecilerden evlere döşenmiş hyperloop sistemi ile iki tane domatesin marketten sipariş verilmesi ile eve gelmesi arasında saniyeler olması" mümkün görünmektedir. Ayrıca perakendeci dükkanında seçilen ürünler, mağazanın dağıtım elemanlarınca (insanlı ya da insansız araçlarla) tüketiciden ayrı ve bağımsız olarak kendi evine ya da istediği başka bir adrese ulaştırma hizmeti sunan pe- 
rakendeciler mevcuttur. Bu durum, tüketici için alışveriş kısmı ile taşıma kısmını ayırma anlamına gelmektedir. Başka bir ifade ile tüketiciler alışverişin zevkli tarafını kendileri yaparken zahmetli tarafını işletmelere bırakabilme alternatifine sahip olacaklardır.

Dükkân kiraları, mala bağlanan paranın maliyeti, satış için yapılan harcamalar (satış elemanı, tutundurma mesajları) gibi giderler azaldığı için pazarlamada etkinlik sağlanarak ürünlerin maliyetleri azaltılabilme imkânı perakendecilerin kar marjını artırabilecektir.

Kültürel olarak birbirine benzeyen ve yakınlaşan bir dünya daha büyük perakendeciler getirirken, otantiklik arayan müşterilere hitap eden ve lokal kültürlere sahip çıkan niş perakendeciler kıymetli olabilecektir.

Perakendecilik sistemi içinde ürünleri tartma paketleme işleri yavaş yavaş tarihe karışmaktadır. Bunların yerine dayanıklı ve farklı gramajı ambalajlar, üzerindeki elektronik okuyucuların (optik, proxy vb.) okuyabileceği barkod, karekod gibi etiketlerin yanında güvenlik devreleri de bulundurmaktadır. Bu işaretleri okuyan sistemlerin insandan bağımsız olmasıyla birlikte perakende mağazalar kendi başına çalışabilen, giderek daha az sayıda satış elemanı çalıştıran ekonomik birimler haline gelmektedir. Perakendecilerin kullandıkları yazılımlarla elektronik olarak değişen etiketler, raflarda azalan ürünlerin takibi, hatta elektronik alışveriş listesiyle mağazaya giren müşteriye mağaza içinde özel rota çizilmesi ve müşteriye özel indirim teklifleri sunan alışveriş sepetleri uzun zamandır sektörde kullanılmaktadır.

Mobil teknolojilerinden faydalanarak mağaza içi müşteri deneyimi oluşturma bağlamında perakendecilik sektöründe yeni bir çı̆̆ır başlatan elektronik perakende şirketi Amazon, "Amazon Go" (Al ve git) uygulamasını tanıtmıştır. Bu mağazada ne bir satış elemanı ne de bir kasiyer vardır. İnsansız mağazaların en azından prototip olarak varlığı, "otonom perakendeciliğin mümkün olacağının bir göstergesi" olarak kabul edilebilir.

Mobil pazarlama iletişimi, perakendeciler için müşteriyi mağazaya doğru hareketlendirmek için kullanılabildiği gibi, mağazaya gelmeden mobil uygulamalar üzerinden müşteri deneyimi yaşamasını, satın almalarda bulunabilmesini, tecrübelerini başkalarıyla paylaşabilmesini, perakendeciye tepkilerini iletmesini sağlayan, hızlı, bireye özel, zengin içerikli mesajlar iletebilme imkânı sunmaktadır. Bu durumun perakendecilerin müşteriler hakkında daha çok bilgi sahibi olması gerektirdiği açıktır. Bigdata olarak da isimlendirilen büyük veri yönetimi ve analiz yöntemleri perakendecilere rekabet avantajı kazandıracak yöntemler olarak öne çıkmaktadır.

Sonucu özetlemek gerekirse mobil teknolojinin perakendecilik sektörü üzerindeki muhtemel etkilerinin şöyle olması beklenmektedir:

- Daha büyük fiziksel perakendeciler

- Daha büyük online perakendeciler

- Geleneksel perakendeciliğin azalması

- Daha yüksek düzeyde perakendeci-tedarikçi işbirlikleri

- Müşterileri özel hissettirecek uygulamaların artması

- Yakın müşteri takibi ve daha yüksek müşteri tatmini

- Azalan işlem maliyetleri

- Otonom perakendecilik

- Tüketim ürünlerine yeni dağıtım alternatifleri

- Lojistik-perakende entegrasyonu 
- Ürün güvenliğinin artması

- Perakendecilik sektöründeki istihdamın azalması ve niteliğin değişmesi

Tüm bu gelişmeler tedarik sisteminde olduğu gibi perakendecilikte de yapay zekâ ve akıllı mağazalar kurulmasını mümkün hale getirmektedir. Satış elemanlarıyla iletişime geçmek isteyen müşteriler dışındaki kişilerin bu sisteme uyum sağlaması da uzun zaman almayacak gibi görünmektedir. 


\section{Eskişehir Osmangazi Üniversitesi IïB Dergisi}

\section{Kaynaklar}

Altunışık, Remzi; Özdemir, Şuayıp; Torlak, Ömer (2017), Pazarlamaya Giriş, 4.Baskı, Sakarya: Sakarya Yayıncılık.

Barutçu, Süleyman (2008), “Mobil Pazarlama”, (Ed. İnci Varinli ve Kahraman Çatı), Güncel Pazarlama Yaklaşımlarından Seçmeler, Ankara: Detay Yayıncılık: 259-285

Barutçu, Süleyman; Göl, Meltem Ö. (2009), “Mobil Reklamlar ve Mobil Reklam Araçlarına Yönelik Tutumlar”, Karamanoğlu Mehmetbey Üniversitesi Sosyal Ve Ekonomik Araştırmalar Dergisi, Cilt.2009, Sayı.2: 24-41.

Becker, Michael; Arnold, John (2010), Mobile Marketing For Dummies, New Jersey: Wiley Publication.

Berman, Barry; Evans, Joel R. (2007), Retail Management, 10 ${ }^{\text {th }}$ Ed., New Jersey: Pearson Education.

Cox, Roger; Brittain, Paul (2004), Retailing an Introduction, $5^{\text {th }}$ Ed., England: Pearson Education.

Craig, Alan B. (2013), Understanding Augmented Reality: Concepts an Applications, Waltham, MA: Elsevier

Deloitte (2015), "Global Power of Retailing 2015: Embracing Innovation", https://www2.deloitte.com/content/dam/Deloitte/global/Documents/Consumer-Business/gx-cb-global-powers-of-retailing.pdf,(Erişim: 17.10.2018).

Dunne, Patric M; Lusch, Robert F; Carver, James R. (2011), Retailing, $7^{\text {th }}$ Ed., Ohio: South-Western Cengage Learning. Ergür, H. Sevil (2015), “Pnömatik Sistemlerde Sağlık ve Güvenlik”, Mühendis ve Makina, Cilt 56, Sayı: 662: 63-71

Friedman, Zack (2018), "Walmart Offers Employees College For \$1 A Day", https://www.forbes.com, (Erişim, 31.05.2018).

Gottlieb, Udo; Bianchi, Constanza (2017), “Virtual Trade Shows: Exhibitors' Perspectives on Virtual Marketing Capability Requirements", Electronic Commerce Research and Applications, Vol.21, January-February, 17-26.

Gülşen, İzzet; Özdemir, Şuayıp (2018), “Perakendecilikte Teknolojik Yenilikler ve Uygulamalar”, Pazarlama Teorisi ve Uygulamaları Dergisi, Cilt.4, Sayı.1: 869-876.

Inman, J. Jeffrey; Nikolova, Hristina (2017), "Shopper-Facing Retail Technology: A Retailer Adoption Decision Framework Incorporating Shopper Attitudes and Privacy Concerns", Journal of Retailing, Vol. 93, No. 1: 7-28.

Jerald, Jason (2016), "The VR Book: Human-Centered Design for Virtual Reality, The Association for Computing Machinery and Morgan \& Claypool Publishers.

Karadağ, Serkan (2017), “Dünyada Akılı Telefon Kullanım Rakamları Açıklandı”, https://www.teknoekip.com, (Erişim: 15 Haziran 2017).

Kemp, Simon (2018), "Digital in 2018", https://wearesocial.com (Erişim: 30.01.2018).

Keskin, Hakan (2018), Lojistik: Tedarik Zinziri Yönetimi, 7. Baskı, Ankara: Nobel Yayın.

Koçel, Tamer (2014), İşletme Yöneticiliği, 15.Baskı, İstanbul: Beta Yayın.

Kotler, Philip; Armstrong, Gary (2018), Principles of Marketing, 17 ${ }^{\text {th }}$ Ed., England: Pearson Education.

Kotler, Philip; Keller, Kevin Lane (2016), Marketing Management, 15 th Ed., England: Pearson Education.

Kumar, Sameer (2008), "A Study of the Supermarket Industry and its Growing Logistics Capabilities", International Journal of Retail \& Distribution Management, Vol. 36, No.3: 192-211.

Laudon, Kenneth C.; Traver, Carol Guercio (2017), E-commerce, 13 ${ }^{\text {th }}$ Ed., England: Pearson Education.

Levy, Michael; Weitz, Barton A. (2012), Retailing Management, $8^{\text {th }}$ Ed., New York: McGraw-Hill Education.

Lindqvist, Ulf; Neumann, Peter G. (2017), "The Future of the Internet of Things", Communications of the Acm, Vol. 60, No.2: 26-30.

Mucuk, İsmet (2007), Pazarlama illkeleri, 16.Baskı, İstanbul: Türkmen Kitabevi.

Mulesoft (2018), "What is an API? (Application Programming Interface)", https://www.mulesoft.com/resources/api/what-is-an-api, (Erişim:10.11.2018)

Murphy, Paul R.; Knemeyer, A. Michael (2018), Contemporary Lojistics, $12^{\text {th }}$ Ed., England: Pearson Education.

Murray, Alan; Papa, Armando; Cuozzo, Benedetta; Russo, Giuseppe (2016), "Evaluating the Innovation of the Internet of Things: Empirical Evidence From the Intellectual Capital Assessment", Business Process Management Journal, Vol.22, No.2: 341-356.

MÜSIAD (2017), "Endüstri 4.0 ve Geleceğin Lojistiği: 2017 Lojistik Sektör Raporu”, http://www.musiad.org.tr/F/Root/Pdf/lojistik_raporlari_2017_12_25.PDF (29.05.2019). 
Ozturk, Ahmet Bulent; Bilgihan, Anil; Esfahani, Saba Salehi; Hua, Nan (2017), "Understanding the Mobile Payment Technology Acceptance Based on Valence Theory: A Case of Restaurant Transactions", International Journal of Contemporary Hospitality Management, Vol.29, No.2: 8, 2027-2049.

Özdemir, Şenel (2017), “Endüstri 4.0, Lojistik Sektörünü Nasıl Etkileyecek?”, https://www.utikad.org.tr/haberler/?id=14666, (Erişim: 29.5.2019)

Özdemir, Şuayıp (2008), Mağaza Yönetimi, 2.Baskı, Ankara: Nobel Yayın.

Perreault, William D; Cannon, Joseph P.; McCarthy, E. Jerome (2017), Essential of Marketing, 15 ${ }^{\text {th }}$ Ed., New York: McGraw-Hill Education.

Porter, Michael E.; Heppelmann, James. E. (2017), "Why Every Organization Needs an Augmented Reality Strategy", Harvard Business Review, November- December

Raj, Pethuru; Raman, Anupama C. (2017), The Internet of Things: Enabling Technologies, Platforms, and Use Cases, Florida: CRC.

Rese, Alexandra; Schreiber, Stefanie; Baier, Daniel (2014), “Technology Acceptance Modeling of Augmented Reality at the Point of Sale: Can Surveys be Replaced by Ananalysis of Online Reviews?", Journal of Retailing and Consumer Services, Vol.21, No.5: 869-876.

Samson, Harland E. (1969), The Nature and Characteristics of Middle Management in Retail Department Stores, Wisconsin: ERIC.

Samuely, Alex (2018), "Minyard Sun Fresh Market adds mobile circulars, coupons to shoppers' carts", https://www.retaildive.com/ex/mobilecommercedaily/minyard-sun-fresh-market-adds-mobile-circulars-coupons-to-shopperscarts, (Erişim: 17.10.2018).

Shankar, Venkatesh (2018), “How Artificial Intelligence (AI) Is Reshaping Retailing”, Journal of Retailing, Vol.94, No.4, VI-XI.

Shankar, Venkatesh; Venkatesh, Alladi; Hofacker, Charles; Naik Prasad (2010), "Mobile Marketing in the Retailing Environment: Current Insights and Future Research Avenues”, Journal of Interactive Marketing, Vol.24, No.2, 111-120.

Solomon, Michael R. (2007), Consumer Behavior: Buying, Having, and Being, 7th Ed., New Jersey: Pearson Education.

Solomon, Michael R. (2017), Consumer Behavior: Buying, Having, and Being, $12^{\text {th }}$ Ed., New Jersey: Pearson Education.

Tek, Ömer Baybars; Özgül, Engin (2013), Modern Pazarlama illkeleri, 4.Baskı, İzmir: Birleşik Matbaacılık.

Varinli, İnci (2012), Marketlerde Pazarlama Yönetimi, 4.Baskı, Ankara: Detay Yayıncılık.

Verhoef, Peter.C.; Lemon, Katherine N.; Parasuraman, A.; Roggeveen, Anne; Tsiros, Michael; Schlesinger, Leonard A. (2009), "Customer Experience Creation: Determinants, Dynamics and Management Strategies", Journal of Retailing, Vol.85, No.1: 31-41. 
Eskişehir Osmangazi Üniversitesi IißBF Dergisi 